MAPS SHOWING GROUND-WATER UNITS, WITHDRAWAL, AND LEVELS, SPRINGS, AND DEPTH TO GROUND WATER, BASIN AND RANGE PROVINCE, NORTHERN CALIFORNIA

by

J. E. Reed, M. S. Bedinger, William H. Langer, R. L. Ireland, and Deborah A. Mulvihill

\title{
INTRODUCTION
}

This report on ground-water units, withdrawal, levels, springs, and depth to ground water in the Basin and Range province of New Mexico (see index map) was prepared as part of a program of the U.S. Geological survey to identify prospective regions for further study relative to isolation of high-level nuclear waste (Bedinger, Sargent, and Reed, 1984), utilizing program guidelines defined in Sargent and Bedinger (1984). Also included in this report are selected references on pertinent geologic and hydrologic studies of the region. Other map reports in this series contain detailed data on ground-water quality, surface distribution of selected rock types, tectonic conditions, areal geophysics, Pleistocene lakes and marshes, and mineral and energy resources. 
In the Basin and Range province, ground water occurs in basin-fill deposits and consolidated rocks. The basin fill consists mostly of unconsolidated to semi-indurated sedimentary deposits. The material ranges from poorly sorted to moderately sorted mixtures of gravel, sand, silt, and clay that were derived from the consolidated rocks in the nearby mountains. Evaporite deposits, limestone, conglomerate, and volcanic rocks are present in places in the unit. Some of the basins may contain as much as 9,000 feet of basin fill, but the most permeable rocks and most of the recoverable ground water is in the upper 1,000 feet of the unit.

The consolidated rocks consist mostly of sedimentary and volcanic rocks, with lesser amounts of metamorphic and intrusive rocks. The consolidated rocks make up the mountain ranges that border the basins and are the principal source of sedimentary material to the basin fill. 


\section{GROUND-WATER UNITS}

This map shows boundaries of ground-water units, generalized directions of ground-water flow at the water table, areas of natural discharge to streams and lakes, areas of natural discharge by evapotranspiration in areas underlain by ground water at shallow depths, and the distribution of consolidated rock outcrops and areas underlain by basin fill.

Ground-water unit boundaries are based primarily on groundwater divides or surface streams. The ground-water table is used to delineate ground-water units in a manner analogous to the way land-surface topography is used to delineate drainage areas. Where information is available, water-level contour maps were used to define the boundaries. Where data on ground-water levels were lacking, ground-water unit boundaries were drawn on topographic divides that were assumed to overlie water-table divides.

Ground-water units shown on the map may contain one or more areas of natural recharge and natural discharge or ground-water withdrawal by wells. Some ground-water units comprise closed flow systems at the water table; that is, no ground-water flow occurs across the ground-water unit boundaries. However, ground-water flow may occur across some unit boundaries.

\section{GROUND-WATER WITHDRAWAL}

The accompanying map shows boundaries of ground-water units, water-use areas (which may in places conform with ground-water unit boundaries), and approximate ground-water withdrawal during 1970 in acre-feet per year, for each water-use area. 
The accompanying map shows the altitude of the ground-water level and the discharge and temperature of selected springs. This information was obtained primarily from reports listed in the "Selected references" and from files of the U.S. Geological Survey. The altitude of the ground-water level is shown by contours in those areas where sufficient data exist. In other areas, where regional data are inadequate to contour, data on selected wells are shown.

Ground-water-level changes occur daily, seasonally, and yearly in response to natural and man-induced hydrologic conditions. The ground-water-level map is a compilation of water-level measurements taken over a number of years. However, for any one ground-water study area the measurements generally were made during a relatively short time period. Collectively, the ground-water levels show the regional configuration of the ground-water surface.

Similarly, water temperatures and discharges of springs may vary with time. The reported values for individual springs were taken at one time; however, collectively the springs were measured over a number of years. Springs may issue from perched water tables or may be under artesian pressure; under these conditions the altitude of springs do not correspond to the altitude of the regional water table.

\section{DEPTH TO GROUND WATER}

The accompanying map shows the approximate depth to ground water below the land surface. In the basin fill, ground water moves in a continuous system, although perched ground water may occur in places. In areas with good topographic control, the depth to ground water can be predicted with reasonable accuracy between widely-spaced water-level data points, except where geologic discontinuities, such as faults, may alter the flow pattern. Where data are sufficiently closely spaced, lines of equal depth to water are shown; where data are inadequate to draw lines, data from selected wells are shown. In consolidated rocks, indicated by shaded patterns on the map, ground water occurs in poorly interconnected joints and fractures; water levels in wells may vary in depth within short distances, and numerous zones of perched water may exist.

Line patterns approximately delineate zones within which the depth to ground water is inferred to be greater than 500 feet. These are highly generalized areas based on very limited data on depth to ground water in wells tapping consolidated rock and basin fill and mine shafts; and on information gained from the location and discharge rates of springs, locations of gaining and losing reaches of streams; and estimates of geohydrologic conditions in areas. The areas delineated as possibly having depths to ground water of greater than 500 feet are recognized as having potential for evaluating prospective environments for isolation of high-level nuclear waste in the unsaturated $z$ one. 


\section{SELECTED REFERENCES}

Bader, J. S., 1969, Ground-water data as of 1967, north coastal subregion, California: U.S. Geological survey Open-File Report, $11 \mathrm{p}$.

1969, Ground-water data as of 1967, northern Lahontan subregion, California: U.S. Geological Survey Open-File Report, $8 \mathrm{p}$.

Bedinger, M. S., Sargent, K. A., and Reed, J. E., 1984, Geologic and hydrologic characterization and evaluation of the Basin and Range Province relative to the disposal of high-level radioactive waste--Part I, Introduction and guidelines: U.S. Geological Survey Circular 904-A, [in press].

California Department of Public Works Division of Water Resources, 1953, Madeline plains drainage basin reconnaissance, Lassen County, Lahontan region: California Department of Public Works, Division of Water Resources, Water Quality Investigations, 3 plates, 28 p.

California Department of Water Resources Division of Resource Planning, 1961, Geology and geohydrology of Surprise ValleyModoc and Lassen Counties: California Department of Water Resources Division of Resources Planning, June 1961, Office Report, 52 p.

California Department of Water Resources, 1960, Geology and geohydrology of Goose Lake Valley, Modoc County, California: California Department of Water Resources, Division of Resources Planning, 4 plates, $28 \mathrm{p}$. 1960, Northeastern counties investgation: California Department of Water Resources, Division of Resources Planning Bulletin no. 58, $312 \mathrm{p}$.

1961, Geology and geohydrology of the Big Valley area, Modoc and Lassen Counties, California: California Department of Water Resources, Division of Resources Planning 3, plates, $38 \mathrm{p}$.

1963, Northeastern counties ground water investigation: California Department of Water Resources Bulletin 98, v. 1 , $224 \mathrm{p}$.

1963, Northeastern counties ground water investigation: California Department of Water Resources Bulletin 98, v. 2, 33 sheets.

1964, Ground water occurrence and quality, Lahontan Region: California Department of Water Resources, Bulletin 106-1, $439 \mathrm{p}$.

Duffield, W. A., and Fournier, R. O., 1974, Reconnaissance study of the geothermal resources of Modoc County, California: U.S. Geological Survey Open-File Report, 21 p.

Hardt, W. F., Olmsted, F. H., an Tralner, F. W., 1975, Susanville-Honey Lake geothermal reconnaissance southern Lassen County, California: U.S. Geological Sruvey and U.S. Bureau of Reclamation Administrative Report, $49 \mathrm{p}$.

Hotchkiss, W. R., 1968, Geologic and hydrologic reconnaissance of Lava Beds National Monument and vicinity, California: U.S. Geological Survey Open-File Report, $30 \mathrm{p}$. 
Iwamura, T. I., and Hail, W. R., 1961, Geology and geohydrology of Madeline Plains, Modoc and Lassen Counties: California Department of Water Resources, Division of Resources Planning Office Report, 3 plates, $29 \mathrm{p}$.

Sargent, K. A., and Bedinger, M. S., 1984, Geologic and hydrologic characterization and evaluation of the Basin and Range Province relative to the disposal of high-level radioactive waste--Part II, Geologic and hydrologic characterization: U.S. Geological Survey Circular 904-B, [in press].

Wood, P. R., 1960, Geology and groundwater features of the Butte Valley region, Siskiyou County, California: U.S. Geological Survey Water-Supply Paper 1491, 150 p. 